\title{
DISTINCTIVE FEATURES OF FARM BUSINESS TRANSFORMATION CHANGES IN VOLYN OBLAST: HUMAN-GEOGRAPHICAL RESEARCH
}

\author{
Yaroslava SOSNYTSKA, Andriy SLASHCHUK, Volodymyr PORUCHYNSKYI \\ Lesya Ukrainka Eastern Euriopean National University, Lutsk, Ukraine \\ 'yaroslavavnu@mail.ru
}

\begin{abstract}
The article defines the modern lines of farm business functioning and underlines the features of these enterprises as perspective business pattern in Volyn oblast. The authors have analyzed the modern state of farms in the region and disclosed their branch specialization and transformation processes on the current stage of their development. The article also discusses regional distinctive features of farm business development in Volyn oblast as well as the basic problems of its functioning.
\end{abstract}

Key words: farm, transformation changes, agriculture, competitiveness, agrarian potential

UDC: 911.3

\section{ОСОБЛИВОСТІ ТРАНСФОРМАЦІЙНИХ ЗМІН ФЕРМЕРСЬКИХ ГОСПОДАРСТВ У ВОЛИНСЬКІЙ ОБЛАСТІ: СУСПІЛЬНО-ГЕОГРАФІЧНІ ДОСЛІДЖЕННЯ}

\author{
'Ярослава СОСНИЦЬКА, Андрій СЛАЩУК, Володимир ПОРУчИНСЬКИЙ \\ Східноєвропейський національний університет імені Лесі Українки, Луцьк, Україна \\ 'yaroslavavnu@mail.ru
}

\begin{abstract}
Анотація: Визначено сучасні риси функціонування фермерських господарств. Підкреслено особливості даної категорії господарств, як перспективних форм господарювання у Волинській області. Проаналізовано сучасний стан фермерських господарств у регіоні, розкрито їх галузеву спеціалізацію та трансформаційні процеси на даному етапі їх розвитку. Висвітлено регіональні особливості розвитку фермерських господарств у Волинській області, основні проблеми їх функціонування.

Ключові слова: фермерське господарство, трансформаційні зміни, сільське господарство, конкурентоспроможність, агропотенціал
\end{abstract}

удк: 911.3

Вступ. Постановка проблеми. Перехід України до нових ринкових умов зумовив виникнення нової форми господарювання - фермерських господарств, які зарекомендували себе як незалежний товаровиробник, що може швидко реагувати до змін ринку і виробляти конкурентоспроможну продукцію, але в той же час має низку проблем, вирішення яких для Волинської області є важливим, оскільки даний регіон відзначаться хорошим агроресурсним потенціалом.

Аналіз останніх досліджень і публікацій. Питання різноукладності економіки та трансформації організаційно-правових форм господарювання у сільському господарстві розглянуто у наукових працях П. Т. Саблука, В. Х. Брус, В. В. Юрчишина, В. Я. Месель-Веселяк, В. П. Нагірної, П. О. Сухого, Г. В. Балабанова, М. Д. Заячука та ін.

Метою статті $\epsilon$ суспільно-географічний аналіз формування та функціонування фермерських господарств Волинської області на сучасному етапі розвитку.

Виклад основного матеріалу. Виникнення фермерства обумовлено сукупністю як об'єктивних, так і суб'єктивних передумов. Насамперед, їх поява пов'язана з кризовим станом аграрної економіки,

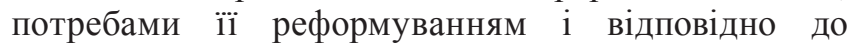
цього необхідністю пошуку таких організаційних

(c) Я. Сосницька, А. Слащук, В. Поручинський структур, в яких найповніше поєднуються інтереси власника івиробника, що, з однієї сторони дозволило б збільшити обсяги виробництва сільськогосподарської продукції, гарантуючи тим самим продовольчу безпеку країни, а з іншого - створити конкурентне середовище в сільському господарстві, внаслідок появи нових приватних структур, що б стимулювало відповідне реформування та трансформацію традиційної колгоспно-радгоспної системи організаціївиробництва.Саместворенняфермерських господарств повинно було забезпечити формування багатоукладності в аграрному секторі економіки, стимулювати формування приватного укладу. Так потреба була обумовлена чітко встановленими суттєвими перевагами індивідуальних особистих підсобних господарств в рівні використання виробничих ресурсів, продуктивності землі над колективними формами ведення господарств $[5 ; 6]$.

Створення фермерських господарств на Волині починалось на землях, виділених у запас у розмірі 7-10 \% із земель колгоспів і радгоспів ще у 1991 році. Закон України «Про селянське (фермерське) господарство» (1993р.) та Земельний кодекс України (1992 р.) дозволяли передавати фермерам у приватну власність, або надавати у користування земельні ділянки, розмір яких не перевищує 50 га ріллі і 100 га усіх земель, а у трудонедостатніх населених пунктах - до 100 га ріллі. У 1995 р. в області нараховувалось 326 селянських (фермерських) господарств. 
у подальшому кількість фермерських господарств і розмір їх землекористування залежав від процесів реформування діючих КСП. Після прийняття Указу Президента України від 3 грудня 1999 р. «Про невідкладні заходи щодо прискорення реформування аграрного сектора економіки», який забезпечив всім бажаючим членам колективних сільськогосподарських підприємств право вільного виходу 3 них, 3 отриманням Державного акту про власність на земельний пай, зростання відбувалось значними темпами [4].

Становлення фермерства залежить від способу утворення фермерських господарств. Порядок їх створення визначається законодавством, але способи їх утворення можуть бути різними. Це зумовлено тим, що господарство може функціонувати лише за умов наявності відповідних ресурсів. Для фермерського господарства як форми господарювання в сільському господарстві визначальним є земля - основний засіб виробництва. Аналіз статистичних даних свідчить про те, що найбільша кількість фермерських господарств у Волинській області створені на основі особистих господарств населення (85,9%), що зумовлене бажанням населення покращити матеріальне становище i задоволення сім'ї в продуктах харчування. Значна частка утворення фермерських господарств на базі розпаювання колишніх колгоспів, що пов'язано із занепадом агроформувнь i нездатністю їх конкурувати на новому ринку. Частка фермерських господарств, що мають статус новостворених становить лише $5 \%$. Стимулювання державою створення фермерських господарств, як показових у Волинській області налічується лише 5. Основний напрям їх діяльності насіннєва і племінна справа [3].

У Волинській області станом на 2013 рік зареєстровано 724 фермерські господарства, що 5 одиниць більше у порівнянні із попереднім роком. Кількість фермерських господарств зростає. Це пояснюється тим, що занепад сільськогосподарського виробництва у сільськогосподарських підприємствах області призвів до їх розпаювання, на основі створюються фермерські господарства. Темпи приросту фермерських господарств у Волинській області простежуються не лише у їх чисельності, але i у темпах зростання сільськогосподарських угідь (рис. 1).

У чисельності фермерських господарств $€$ регіональні відмінності. Найвища кількість фермерських господарств спостерігається у Горохівському (124), Ковельському (102), ВолодимирВолинському (89) та Луцькому (78) районах. Найменше фермерських господарств зосереджено у Любомльському (8), Маневицькому (5) та Шацькому (3) районах.

За досліджуваний період відбулося зростання середнього розміру фермерського господарства удвічі. Середній розмір фермерського господарства у Волинській області становить 44 га. Найвищий цей показник у Турійському районі і становить 236 га. Більший за середньообласний розмір фермерського господарства у Горохівському (54 га), Рожищенському (52 га) і Ковельському (45 га) районах. Найнижчий у Камінь-Каширському (12 га) та Шацькому (7 га) районах. Це пояснюється кращими агроресурсами у південній частині області, що дає змогу більшій рентабельності господарства [2].

Проведене групування фермерських господарств досліджуваного регіону свідчить про те, що за розмірами їх можна поділити на три групи:

- дрібноземельні формування площею до 10 га землі (189 господарств у

2012 р.), які характеризуються низькою технічною оснащеністю, працює в таких господарствах переважно 1-3 працівники;

- середньоземельні господарства, в яких розмір земельного наділу становить 11-50 га (267 підприємств). Це сімейні фермерські господарства, які мають власну техніку та здійснюють сезонний найм робочої сили;

- великоземельні господарства 3 площею понад 50 га (131 підприємство), які мають високий рівень

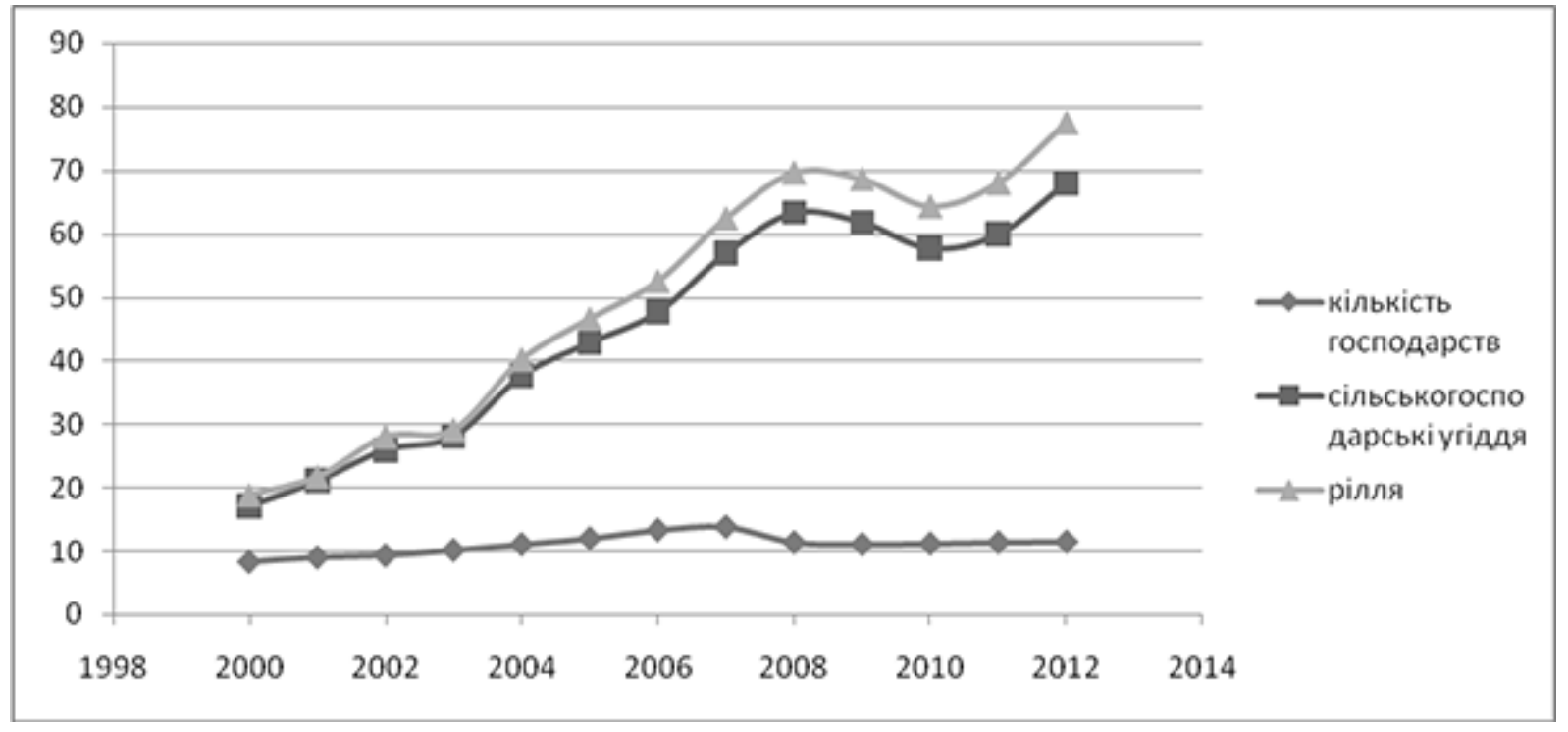

Рис. 1. Темпи приросту фермерських господарств у Волинській області 


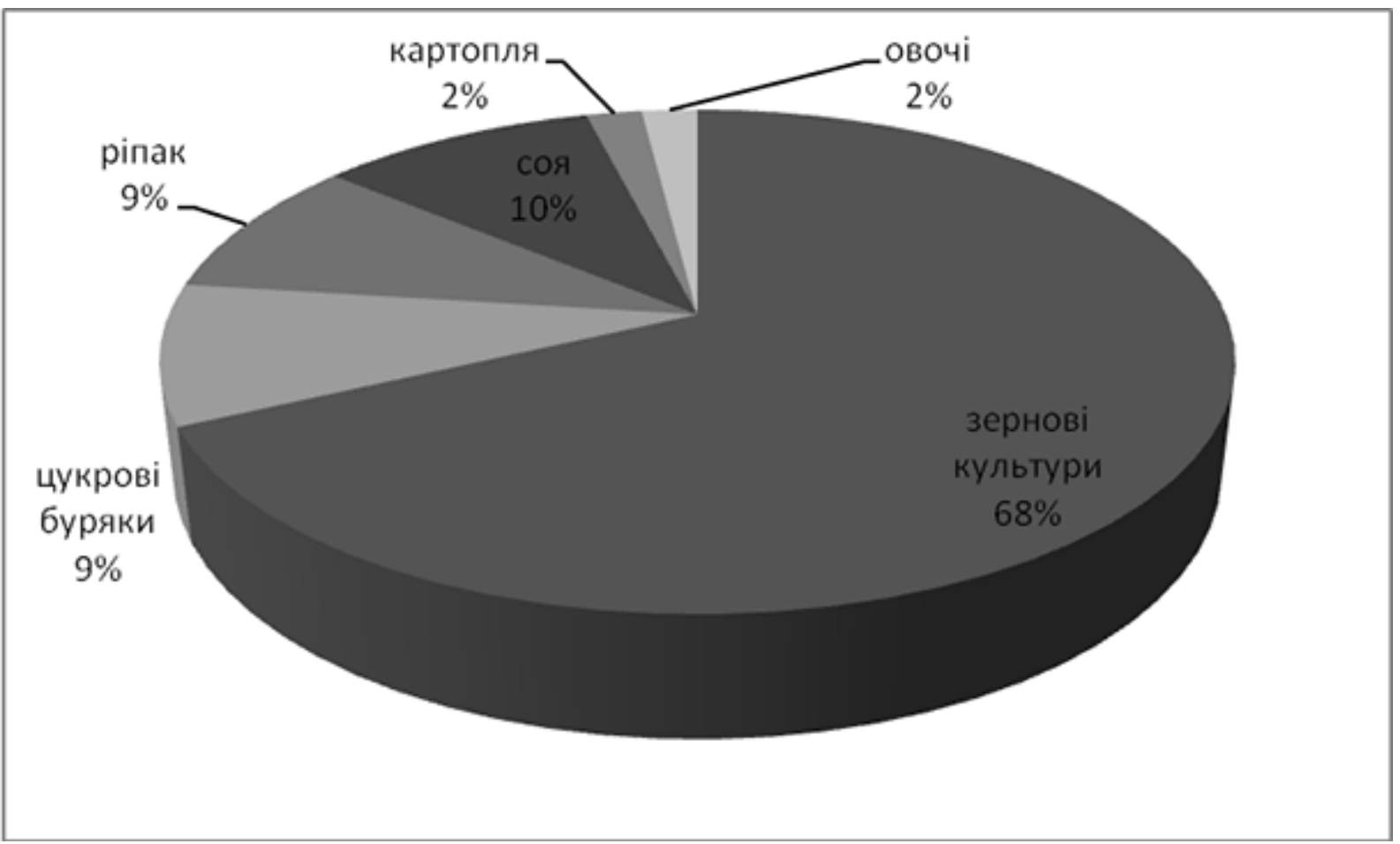

Рис. 2. Структура посівної площі фермерських господарств у 2012 р.

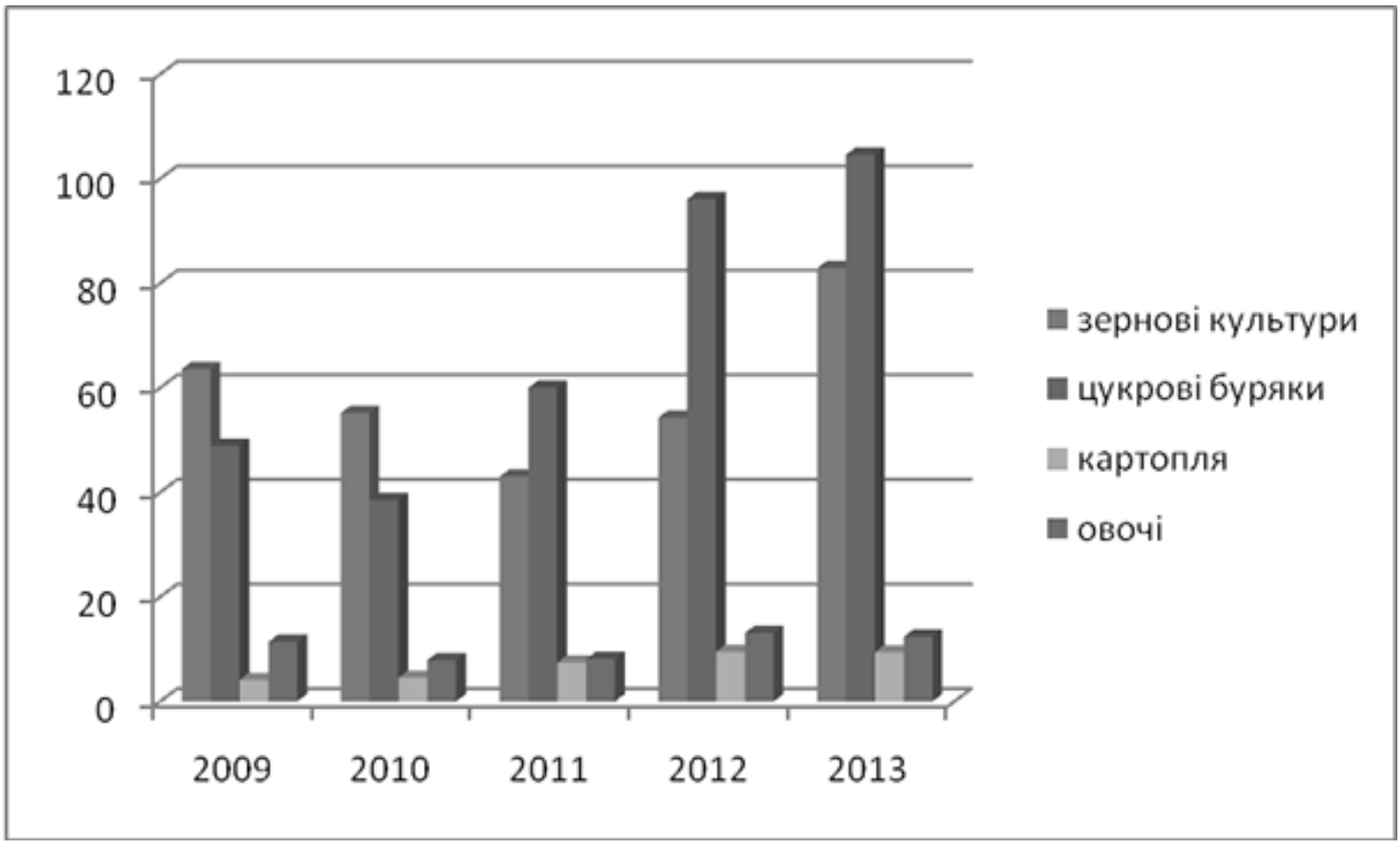

Рис. 3. Динаміка виробництва основних сільськогосподарських культур фермерськими господарствами, тис. т.

забезпечення технікою, практикується постійне використання найманих працівників та оренди землі, в тому числі земельних часток (паїв) колишніх членів колективних (кооперативних, акціонерних) сільськогосподарських підприємств. Найбільші земельні площі (понад 3000 га) обробляють в області лише 3 фермерські господарства області - «Аміла» та «Перлина Турії» Турійського, «Надія» Локачинського районів [5].

Основним елементом виробництва та формування ресурсів у фермерському господарстві є наявність робочої сили, яка здатна привести в дію наявні засоби виробництва. Результативність господарської діяльності фермери в значній мірі залежить від забезпеченості ㄲi трудовими ресурсами, їх професійно-кваліфікаційного рівня, здатності реалізувати свою потенційну продуктивну силу. Фермерські господарства, як переважно господарства сімейні, значно обмежені у своїй діяльності та формуванні виробничої програми саме через малий трудовий потенціал. Проте, достатньо обгрунтований підхід до раціонального поєднання 
ресурсів сприяє кращому їх використанню саме в дрібних господарствах [3].

Загальна кількість працюючих у фермерських господарствах Волинської області у 2012 році становить 1624 особи, що із попереднім роком на 259 особи менше. Із них лише 63 \% (1028 осіб) наймані працівники. У розрахунку на 100 га сільськогосподарських угідь припадає 4 працівника. Цей показник із кожним роком зменшується і це пояснюється збільшенням розмірів фермерських господарств.

Найвища кількість працюючих у фермерських господарствах спостерігається у Турійському (295 особи), Горохівському (277), Ковельському (156), Локачинському (138), Луцькому (123) та Ківерцівському (118) районах. Найменша у Шацькому - лише 2 працівника.

Не дивлячись на значну частку найманих працівників, залишається значна частка неоплачуваних працівників у фермерських господарствах Волинської області (37 \% від усіх працюючих). Найчастіше це власники фермерських господарств і члени їх сімей.

Великою проблемою у фермерських господарствах області залишається матеріальнотехнічна база, яка є застарілою, як фізично, так i морально і якої немає у достатній кількості.

Станом на 1 січня 2013 року у фермерських господарствах зареєстровано 563 тракторів (20,2 \% від усіх тракторів, що зареєстровані у всіх сільськогосподарських підприємствах), 224 зернозбиральних комбайнів (29,0 \%), 39 картоплезбиральних машин $(38,6$ \%), 47 бурякозбиральних машин $(49,0 \%), 207$ сівалок $(23,7 \%)$ і 69 картоплесаджалок (56,1 \%).

Спостерігаються і регіональні відмінності у забезпеченні технікою. За наявністю тракторів найкраща ситуація спостерігається у Турійському $(98$ одиниць), Горохівському (75 одиниць), Луцькому (74 одиниць), Локачинському (70 одиниць) і ВолодимирВолинському (64 одиниці) районах. Найгірша ситуація спостерігається у Маневицькому (1 одиниця), Любещівському (2 одиниці) та у Шацькому (3 одиниці) районах.

Протилежна ситуація щодо навантаженості на 1 трактор ріллею. Найвища завантаженість спостерігається у Іваничівському (109 га на 1 трактор), Маневицькому (104 ріллі на одиницю техніки), Горохівському (101га на одиницю техніки). Найменша навантаженість у Камінь-Каширському (13 га ріллі на 1 трактор), Ратнівському (12 га ріллі на 1 трактор) та Шацькому (2 га ріллі на 1 трактор) районах.

Найбільше зернозбиральних комбайнів спостерігається у Горохівському (54 одиниці), Турійському (34 одинииці), Ковельському (32 одиниці) та Володимир-Волинському (27 одиниці) районах. Найменша кількість даної категорії техніки зареєстрована у Любешівському (1 одиниця), Маневицькому (2одиниці) та у Любомльському (3) районах. Проте завантаженість на один зернозбиральний комбайн га посіву зернових спостерігається у Іваничівському (254 а на одиницю техніки) та в Рожищенському (232 га на одну одиницю техніки) районах. А найменша у Камінь-Каширському районі - 18 га на один зернозбиральний комбайн.

Для покращення урожайності сільськогосподарських культур та родючості грунтів багатьма фермерськими господарствами відбувалось внесення мінеральних та органічних добрив. Проте диспаритет цін зумовив ситуацію, що у 2012 році лише 56,8 \% усіх фермерських господарств вносили мінеральні добрива і 18,8 \% органічних добрив. Проте цей показник значно відрізняється у районах області. Вищий за середньообласний показник по внесенням мінеральних добрив спостерігається у Локачинському (91,5 \%), Горохівському (75 \%), Любомльському (68,4 \%), Луцькому (61,5%), КаміньКаширському (60,7 \%) і у Володимир-Волинському $(59,6 \%)$ районах. Найнижчий цей показник у Любешівському районі - 12,5 \% фермерських господарств вносили мінеральних добрив у грунт.

Внесення органічних добрив у грунт фермерськими господарствами залежить від спеціалізації самого господарства. Вища частка внесення органічних добрив спостерігається у фермерства тваринницького напрямку і характерна для Камінь-Каширського (67,9\% від усіх господарств), Ковельському (29,4\%), Луцькому (39,7\%), Шацькому $(33,3 \%)$ районах. Жодне фермерське господарство не вносило органічних добрив у грунт у 2012 році у Локачинському районі.

Найвища частка сільськогосподарських угідь, що належить фермерським господарствам у Турійському (6,89 тис. га), Горохівському (5,92 тис. га), Ковельському (3,5 тис. га) та Локачинському $(2,84$ тис. га). Найменший цей показник у Шацькому районі (7 га). Спостерігаються територіальні відмінності у структурі розподілі сільськогосподарських угідь. У всіх районах значно переважає рілля. Найвища iii частка у Шацькому (100 \%), Луцькому (99 \%), Горохівському (97\%), Камінь-Каширському (96 \%) та Старовижівському (95 \%) районах. На даний показник впливають не природно-географічні фактори, а напрям виробництва - рослинництво.

Найвища частка сіножатей i пасовищ $\mathrm{y}$ Любешівському (31 \%), Любомльському (28\%), Маневицькому (24 \%) i Ківерцівському (21\%) районах. Саме у цих районах функціонують найбільше фермерських господарств тваринницького напрямку.

Значні трансформаційні зміни фермерських господарств відбулись у структурі посівних площ. Аналіз структури посівних площ свідчить про зменшення посівних площ під зерновими культурами на $20 \%$, зокрема у південних районах області, які мають найбільш сприятливі умови для вирощування зернових культур у Волинській області. Витіснення даних культур відбувається за рахунок значних посівних площ під культурами, які $€$ менш притаманними для регіону - ріпаком $\mathrm{i}$ соєю. Це зумовлено наявність значних ринків збуту - переробних підприємств. Збільшення частки посівних площ спостерігається під цукровими буряками, 


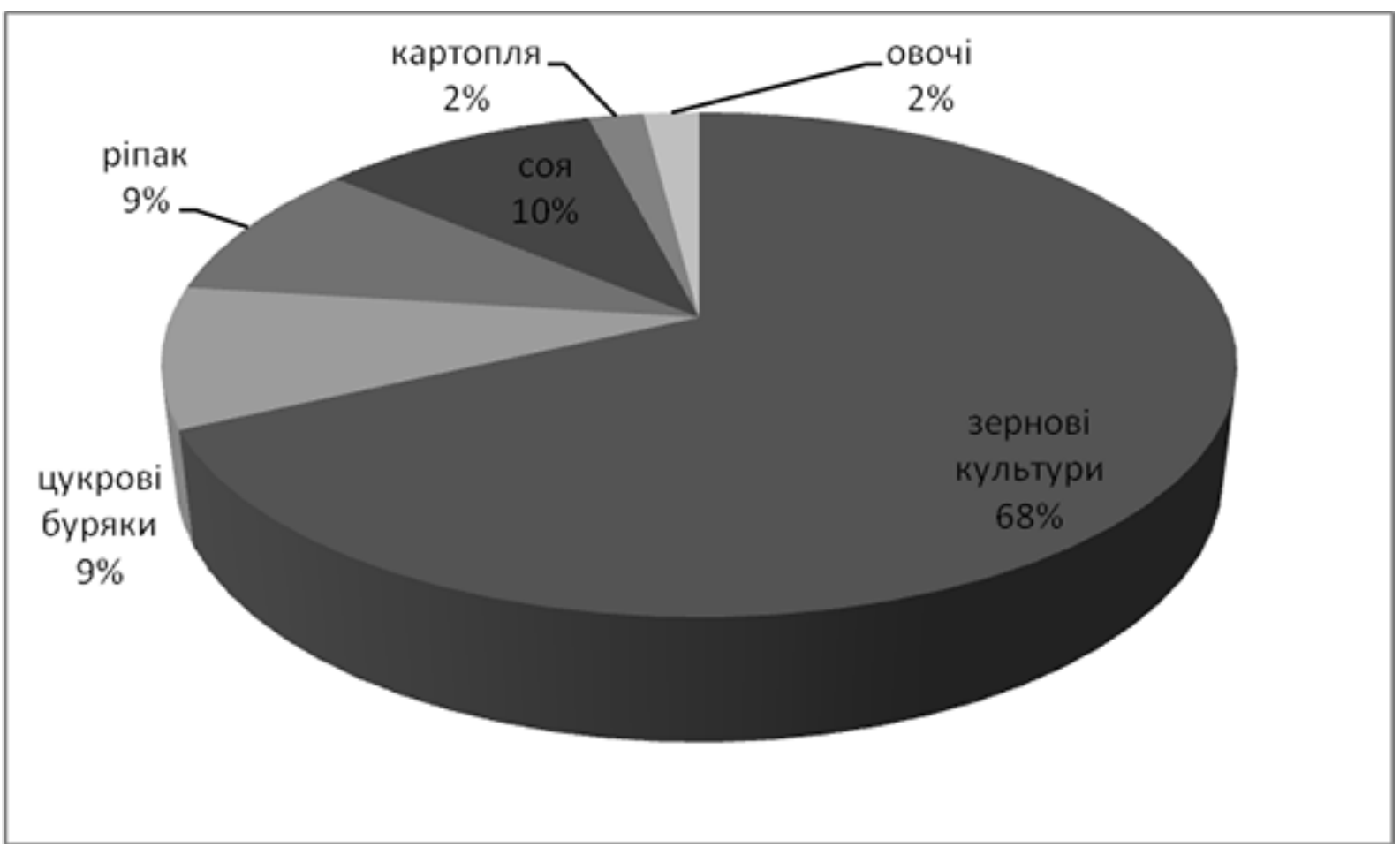

Рис. 2. Структура посівної площі фермерських господарств у 2012 р.

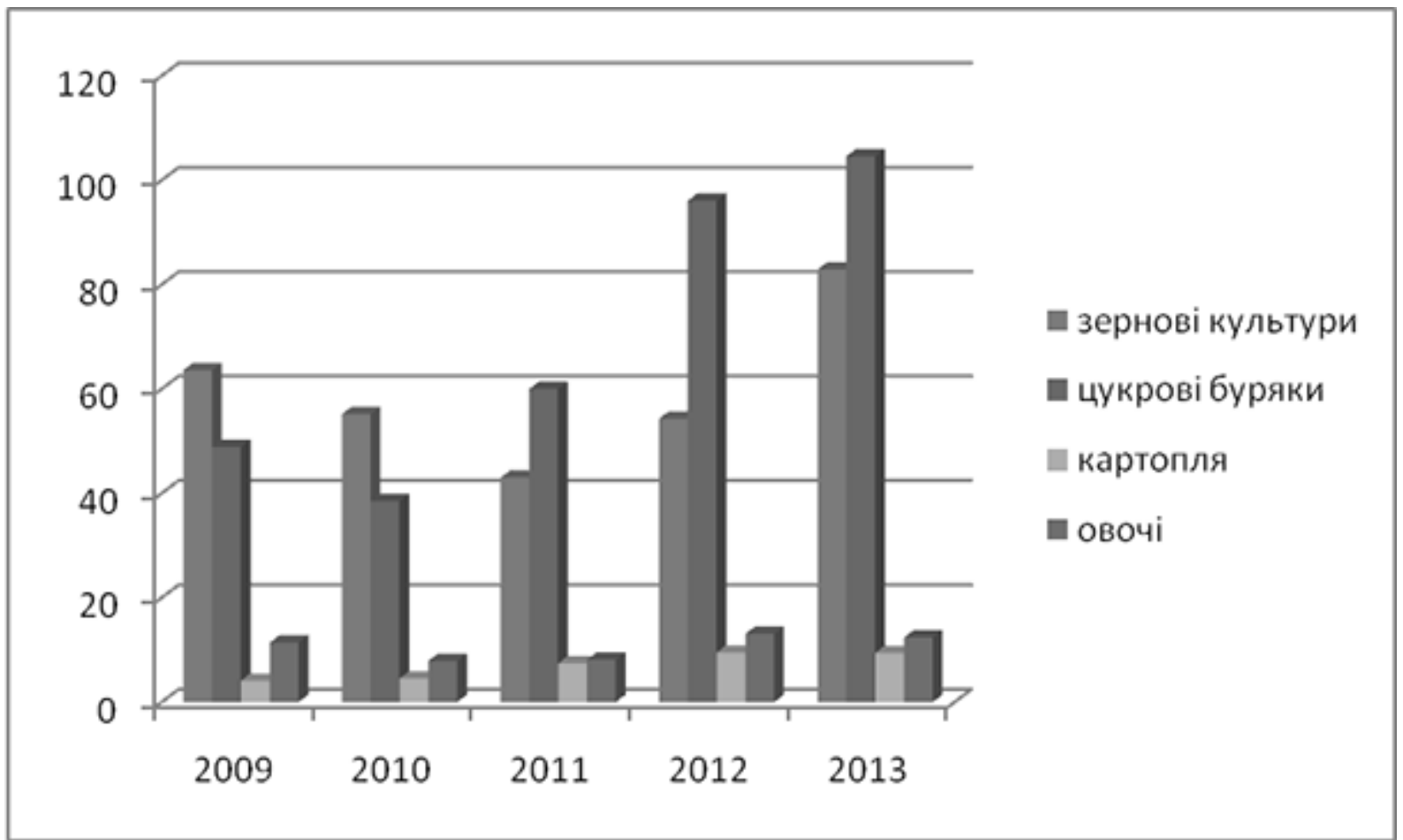

Рис. 3. Динаміка виробництва основних сільськогосподарських культур фермерськими господарствами, тис. т.

картоплею та овочами відкритого грунту на $1 \%$. Ці культури фермерські господарства в більшості використовують для власних продовольчих потреб (рис. 2).

Аналіз статистичних даних свідчить про те, що 85,2 \% усіх фермерських господарств Волинської області мають рослинницький напрям ведення господарства. Лише у Ківерцівському, Рожищенському, Любомльському, Маневицькому та Любешівському районах цей показник нижчий за середньообласний.
У 2012 році фермерськими господарствами Волинської області було вироблено сільськогосподарської продукції на суму 582,8 млн грн., що становить 4,2 \% від усієї валової продукції сільського господарства області.

Із загального обсягу усієї сільськогосподарської продукції на рослинництво припадає 81,4%, що підтверджує рослинницьку спеціалізацію фермерських господарств.

Зберігаються тенденції, щодо зростання виробництва основних сільськогосподарських 
культур фермерськими господарствами. За досліджуваний період виробництво зернових культур зросла на чверть, цукрових буряків, картоплі та овочів відкритого грунту удвічі (рис.3).

У 2013 р. усіма фермерськими господарствами вироблено 85,5 тис. т зернових і зернобобових культур (10 \% від загальнообласного виробництва зернових усіма категоріями господарств. Найбільше виробництво зернових припадає на фермерські господарства Турійського (18,670 тис. т), ВолодимирВолинського (16,463 тис. т) та Горохівського (16,043 тис. т) районів. Найменший цей показник у Камінь-Каширському (89 т), Ратнівському (71 т), Любешівському (46 т), Любомльському (46 т) та Маневицькому (35 т) районах.

У структурі виробництва зернових культур 47 \% припадає на виробництво озимої пшениці $(38,939$ т). Друге місце займає кукурудза (26 \% від валового збору зернових культур). Ячменю фермерськими господарствами вироблено у 2013 р. 7,992 тис. т (10 $\%$ від загального обсягу виробництва зернових). Незначна частка зернових припадає на жито (8 \%), не дивлячись на те, що для вирощування даної культури у Волинській області найсприятливіші агрогрунтові умови. Значна частка припадає на виробництва вівсу, це й показник свідчить про розвиток конярства і низьку матеріально-технічну базу фермерських господарств. Решта припадає на виробництво проса, гречки та зернобобових.

Середній урожайність зернових культур у фермерських господарствах становить 35,3 т/га. Цей показник на 6 т менший за аналогічний показник ніж у сільськогосподарських підприємствах і на 7 т більший ніж у підсобних господарствах населення. Урожайність зернових культур зростає у південному напрямку, відповідно вона найбільша у Горохівському районі і становить 42,7 т/га, найменша у Ратнівському - 21,1 т/га.

Найбільші трансформаційні зміни відбулись у структурі посівів та валового збору технічних культур. Традиційну культуру для південних районів області - цукровий буряк доповнили ріпак та соя, які займають більшу посівну площу ніж цукрові буряки.

У 2013 р. фермерськими господарствами Волинської області зібрано 93,245 тис. т цукрових буряків. Що на 30 \% більше ніж у 2009 році. Основними виробниками цукрових буряків $\epsilon$ фермерські господарства Горохівського (32 \% від загальнообласного виробництва фермерськими господарствами), Турійського (21 \%), ВолодимирВолинського (15 \%), Локачинського (13 \%), та Луцького (7 \%) районів.

Середня урожайність цукрових буряків у фермерських господарствах Волинської області становить 362 ц/га. Найвищий цей показник у Іваничівському (461 ц/га), Турійському (456 ц/га) та Горохівському (432 ц/га) районах.

У 2013 р. усіма фермерськими господарствами зібрано 9484 т ріпаку та 8280 т сої. Це у 20 раз більше ніж у 2009 році. Дані технічні культури вирощуються у південних районах області, через сприятливість агрокліматичних умов та близького ринку збуту.

Оскільки $85 \%$ фермерських господарств Волинської області є сімейного типу, то для власного споживання вони виробляють картоплю та овочі відкритого грунту для власного споживання. Частка виробництва картоплі та овочів до загального виробництва аналогічної продукції усіма категоріями господарств у Волинській області становить 0,5 \% i 1,4 \% відповідно.

Частка валового виробництва тваринницької продукції фермерськими господарствами області до загальної виробництва усієї сільськогосподарської продукції даною категорією господарства становить 14,8 \%. Такий низький показник свідчить про те, що продукція тваринництва $€$ нерентабельною $(-24,5 \%)$.

Станом на 1 січня 2013 р. у фермерських господарствах населення чисельність ВРX налічує 5895 голів, у тому числі 2405 корів. Найвища частка ВРX серед фермерських господарств належить Турійському (47 \% від загального показника), Горохівському (14 \%) та Ковельському (9 \%).

Територіальні відмінності характерні для свинарства у фермерських господарствах населення. Найвищий показник по чисельності свиней у даній категорії господарств спостерігається у ВолодимирВолинському (7130 голів), Турійському (2028 голів), Луцькому (1779 голів) та Горохівському (1100 голів). Зосередження даного напрямку тваринництва у південних районах області зумовлений наявністю зернового комплексу.

У виробництві та реалізації тваринницької продукції спостерігаються тенденції щодо зменшення виробництва молока удвічі за досліджуваний період та на зростання виробництва м'яса у живій вазі.

Крім виробництва сільськогосподарської продукції фермерські господарства займаються додатковими видами діяльності. Найбільш поширені 3 них - перевезення вантажів (надавало такі послуги $1,1 \%$ фермерських господарств), торгівля (0,8 \%), переробка сільськогосподарської продукції та лісове господарство (по 0,3%), виробництво кормів для тварин $(0,1 \%)$. Іншими видами діяльності займалося 2,6 \% фермерських господарств [2].

Проблемою для кожного фермера $є$ не тільки виробництво. Умісно відмітити, що весь успіх сільськогосподарської діяльності $€$ складовою вдалого менеджменту виробництвом, фінансами та маркетингом. Відомо є те, що кожна з цих складових менеджменту в рівній мірі впливає на кінцевий результат.

Традиційно, фермери, як i колишні, так i в достатній мірі i сучасні, керівники сільськогосподарських підприємств основну увагу приділяють саме виробництву. В той же час управління фінансами зводиться до розподілу тих фінансових ресурсів, якими володіє господарство. Ніяких розробок щодо ефективного застосування фінансів, розробки багатоваріантних фінансових планів, різних можливих виробничих програм 3 достатнім фінансовим обгрунтуванням, а тим більше 
оцінкою фінансових ризиків, не проводиться i, цілком очевидно, ця сфера діяльності в найближчому майбутньому буде для керівників аграрних формувань не доступною. Очевидно, що тут не вистачає не лише знань керівників, а всієї системи 3 фінансів, відсутності відповідних інституцій на ринку.

В цілому оцінюючи результати діяльності фермерських господарств слід відмітити, що вони є недосконалими. Це пов'язано із значними труднощами у ведені цих господарств, передусім в формуванні ресурсної бази та збалансованості окремих піï елементів. Тільки за умови вирішення цих проблем можна очікувати дальшого розвитку фермерського укладу, утворення повноцінних i конкурентоспроможних фермерських господарств [C].

Висновки. Отже, у Волинській області не дивлячись на ряд проблем пов'язаних із диспаритетом цін, незадовільною матеріально-технічною базою, низьким інформаційним забезпеченням існує тенденція щодо зростання фермерських господарств, збільшення посівних площ та наростанням обсягів виробництва сільськогосподарської продукції.

\section{References:}

1. Berezìvs'kij P. S., Mihajlûk P. S. Organizaciâ virobnictva vagrarnih formuvannâh [Industrial engineering in agrarian formations]. Kyiv, 2005, pp. 39-105. (In Ukrainian).

2. Fermeri Volini: statističnij zbìnik [Volhynian farmers: a statistical compendium]. Lutsk, 2013 , 90 p. (In Ukrainian).

3. Onis'ko S. M., Lipčuk V. V. et al. Regional'nì osoblivostì stanovlennâ ta rozvitku fermerstva [Establishment and development of farming: regional peculiarities]. Lviv, 2001, pp. 30-34. (In Ukrainian).

4. Ruŝak V. M. Stanovlennâ ta rozvitok fermers'kogo zemlekoristuvannâ u Volins'kìj oblastì [Establishment and development of private land use in Volyn oblast]. Visnik Tavrìjs'kogo deržavnogo agrotehnologičnogo universitetu [Bulletin of Tavrida State Agrotechnological University], 2013, Vol. 1, pp. 279-287. (In Ukrainian).

5. Sabluk P. T. (ed.). Reformuvannâ ta rozvitok pidpriêmstv agropromislovogo virobnictva (posibnik u pitannâh ta vidpovidahh) [Reforming and development of agro-industrial production enterprises (manual in questions and answers)]. Kyiv, 1999, pp. 18-22. (In Ukrainian).

6. Suhij P. O. Agroprodovol'čij kompleks Zahidnoukrä̈ns'kogo regionu [Agrifood complex of the Western Ukraine]. Author's abstract of Doctoral Thesis. Chernivtsi, 2009, pp. 3-32. (In Ukrainian).

7. Zaâčuk M. D. Do pitannâ funkcìonuvannâ fermers'kih gospodarstv u Pìvnično-Zahìdnomu regìonì Ukraïni [To the question of the farm business functioning in the North-West region of Ukraine]. Naukovij visnik Volins'kogo nacional'nogo unìversitetu imeni Lesi Ukrä̈nki. Seriâ.: Geografični nauki [Scientific Bulletin of Lesya Ukrainka Volyn National University. Series: Geography], 2009, Vol. 2, pp. 76-83. (In Ukrainian). 